\title{
En eldre mann med hjertesvikt
}

\author{
En mann i 80-årene hadde over lengre tid blitt behandlet for hjertesvikt \\ som man trodde skyldtes arteriell hypertensjon. Da symptomene økte, \\ ble det imidlertid påvist en annen bakenforliggende sykdom.
}

En mann i 80-årene ble innlagt ved medisinsk avdeling på lokalsykehuset grunnet raskt økende plager med tung pust. Han var nylig tilflyttet distriktet og hadde fått diagnosen hjertesvikt ved et annet sykehus. I innleggelsesskrivet ble det opplyst at han fra tidligere også hadde paroksysmal atrieflimmer, lett nyresvikt, lett aortastenose og ubehandlet kronisk obstruktiv lungesykdom (kols). Han hadde røykt tidligere og hadde hatt to tilfeller av dyp venetrombose i underekstremitetene. Pasientens faste medikasjon var warfarin, digitoksin, ramipril, metoprolol, bumetanid og allopurinol. Ved innleggelsen hadde han regelmessig hjerteaksjon med 88 slag/min, og blodtrykket var 137/85 $\mathrm{mm} \mathrm{Hg}$ og han var afebril. Over lungene ble det funnet basale inspiratoriske knatrelyder ved auskultasjon og basal dempning ved perkusjon. Det ble auskultert en svak systolisk bilyd over prekordiet, og han hadde deklive ødemer i underekstremitetene.

Kapillær oksygenmetning var kun $82 \%$ ved respirasjon $i$ romluft. Blodprøver ved innkomst (tab 1) viste blant annet $C$-reaktivt protein (CRP) $30 \mathrm{mg} / \mathrm{l}(0-6 \mathrm{mg} / \mathrm{l})$ og normale leukocytter. Kreatinin var forhøyet, samtidig som estimert glomerulusfiltrasjonsrate (GFR) var under nedre referansegrense. Både hjernenatriuretisk peptid (BNP) og troponin I var forhøyet (tab 1). Protein i urin viste serumliknende mønster og ble funnet lett forhøyet $10,5 \mathrm{~g} / \mathrm{l})$. Ratio mellom protein og kreatinin $i$ urin ble ikke målt. EKG viste sinusrytme, AV-blokk grad 1 med $P Q$-tid 250 ms, Q-takker suspekt på tidligere gjennomgått lateralveggsinfarkt, generelt litt repolariseringsforandringer, dårlig progresjon av R-takkene i mediale prekordialavledninger og spredte ventrikulære ekstrasystoler (fig 1). Røntgen thorax viste stuvningsforandringer i lungene.

På grunnlag av sykehistorie, kliniske funn og resultater fra supplerende undersøkelser vurderte vi akutt forverring av pasientens hjertesvikt som den mest sannsynlige årsak til symptomene. Pasienten hadde ikke hatt brystsmerter, og ved innkomst ble hjertesvikten sammen med nedsatt nyrefunksjon tolket som sannsynlig årsak til det forhøyede troponinnivået. CRP var bare lett forhøyet, leuko- cytter og kroppstemperatur var normale, og røntgen thorax viste ingen infiltrater. Tillegg av pneumoni eller annen potensielt alvorlig infeksjon var derfor lite sannsynlig.

Vi startet overtrykksventilasjonsbehandling med positivt luftveistrykk med to nivåer (bilevel positive airway pressure, BiPAP), diuretika og ekstra oksygentilskudd. Dette ga raskt klinisk bedring av hjertesvikten. Pasienten kunne slutte med BiPAP og ekstra oksygentilskudd etter få dager og hadde da kapillær oksygenmetning stabilt over $90 \%$. Hjerterytmen vekslet mellom sinusrytme og atrieflimmer, og det ble etter hvert startet med amiodaron for å stabilisere sinusrytmen. Digitoksin ble seponert. Det ble omsider kjent at pasienten de siste årene hadde vært innlagt flere ganger $i$ annet sykehus grunnet hjertesvikt, og han hadde også vært fulgt opp med flere kontroller ved sykehusets hjertepoliklinikk. Arsaken til hjertesvikten ble i epikriser derfra opplyst å være arteriell hypertensjon. Det var påvist biventrikulær hjertesvikt, og ved ekkokardiografi hadde man sett hypertrofiert venstre ventrikkel med normal ejeksjonsfraksjon og dessuten en beskjeden aortastenose.

Årsaken til pasientens forverring var imidlertid uavklart. EKG-funn og myokardmarkører gjorde at vi verken kunne avskrive akutt eller gammelt hjerteinfarkt som bakenforliggende årsaker. Aortastenosen kunne også tenkes å ha progrediert. Den underliggende årsaken til hjertesvikten måtte vurderes på nytt da blodtrykksmålinger under oppholdet kun viste normale og lave verdier. Pasienten anga dessuten selv at han aldri hadde hatt høyt blodtrykk.

Vi undersøkte pasienten videre med ekkokardiografi. Det forelå ingen perikardvæskeansamling. Venstre ventrikkel var generelt tydelig hypertrofiert med veggtykkelser på $1,6-1,7 \mathrm{~cm}$ (normale veggtykkelser $\leq 1,1 \mathrm{~cm}$ ) (fig 2). På grunn av hypertrofien hadde ventrikkelen liten kavitet med endediastolisk tverrdimensjon på $3,9 \mathrm{~cm}$ (normalområde 4,2-5,9 cm). Ventrikkelen viste hypernormal tverrkontraktilitet $i$ alle avsnitt uten tegn til infarktsekvele, mens lengdekontraktiliteten

\author{
Anna Widding Langsholdt* \\ anna_lang@yahoo.com \\ Johnny Vegsundvåg \\ Medisinsk avdeling \\ Ålesund sjukehus \\ Helse Møre og Romsdal
}

* Nåværende adresse

Sunndal Medisinske senter

Sunndalsøra

Se kommentar side 2507

Engelsk oversettelse på www.tidsskriftet.no 
Tabell 1 Oversikt over laboratorieverdier ved innkomst og referanseområder for de ulike prøvene

ASAT (U/L)

LDL (mmol/l)

Hjernenatriuretisk peptid (pmol/l)

Troponin-I (ng/l)

Digitoksin (mmol/l)

U-protein (g/l)

var redusert. Ventrikkelens ejeksjonsfraksjon viste normal verdi på $65 \%$. Det forelå ingen systolisk intrakavitær avklemming i ventrikkelen. Mitralklaffen hadde noe fortykkede seil med god bevegelighet og en liten lekkasje.

Blodstrømshastigheter gjennom mitralklaffen og vevshastigheter ved mitralringene indikerte samlet forhøyet fyllingstrykk $i$ venstre ventrikkel. Aortaklaffen var trikuspid med fortykkede kusper som viste ganske god åpningsbevegelighet, og det ble beregnet et åpningsareal på minst $1,5 \mathrm{~cm}^{2}$. Ved dopplerundersøkelse ble middel-/maksimalgradienten over aortaklaffen målt til 10/17 mm Hg. Det forelå dessuten en minimal lekkasje i kommisurkontaktpunktet mellom de tre aortakuspene. Høyre ventrikkel hadde normale indre dimensjoner og viste god kontraktilitet. Vena cava inferior var imidlertid utvidet, og respiratoriske kalibervekslinger var redusert til bare $20 \%$ under vanlig respirasjon. Dette indikerte forhøyet fyllingstrykk i høyre ventrikkel. Det forelå en trikuspidallekkasje av moderat størrelse. Maksimalgradienten over denne var $30 \mathrm{~mm} \mathrm{Hg}$, som tillagt et forhøyet høyre atrietrykk indikerte systolisk pulmonalarterietrykk på $40-45 \mathrm{~mm} \mathrm{Hg}$. Fri vegg på
Verdi

30

15,8

5,7

208

151

38

20,9

4,6

143

2,22

36

6,6

12

1,06

\section{2,1}

26

$\begin{array}{rr}2,6 & 1,4-4,7 \\ 194 & 0-30 \\ 267 & 0-28 \\ 16 & 8-16 \\ 0,5 & \end{array}$

Referanseområde

\section{$<5$}

$11,7-15,2$

$3,5-11.0$

$145-390$

$60-100$

$>60$

$3,5-8,1$

$3,5-4,4$

$137-145$

$2,15-2,51$

$36-45$

$4,2-6,3$

$11-17$

$0,50-3,60$

$0,8-1,2$

$14-45$

$-4,7$

$-28$

$8-16$

0,5

høyre ventrikkel målte $1,1 \mathrm{~cm}$ i tykkelse (normal tykkelse $\leq 0,5 \mathrm{~cm}$ ). Pulmonalklaffen var normal. Begge atrier var moderat forstørrede. Atrieseptum var fortykket til $1,1 \mathrm{~cm}$. Myokard i begge ventrikler ga et påfallende granulært uttrykk (fig 2).

Pasienten hadde altså en betydelig hypertrofi av venstre ventrikkel, og dette kunne i hans tilfelle vanskelig forklares av arteriell hypertensjon eller den beskjedne aortastenosen. Det lett forhøyede systoliske pulmonalarterietrykket kunne tilskrives venstresidig hjertesvikt og kunne ikke forklare den betydelige hypertrofien av høyre ventrikkels frie vegg. At hypertrofien omfattet begge ventriklene, ga derimot mistanke om restriktiv kardiomyopati, og de samlede ekkokardiografiske funnene ga mistanke om hjerteamyloidose. De to vanligste årsakene til amyloidavleiring i hjertet er overproduksjon av monoklonale lette immunglobulinkjeder (AL-amyloidose) og transtyretinrelatert sykdom (familiær og senil type) (1).

Serum-immunelektroforese og serumnivåer av lette immunglobulinkjeder var normale uten påvisbar monoklonal komponent, og det ble ikke funnet Bence Jones' proteiner i urinen. Ut ifra disse funnene var det ikke holdepunkter for AL-amyloidose. Scintigrafi av pasienten med ${ }^{99 m} \mathrm{mc}$-3,3-difosfono-1,2-propandikarboksylsyre (99mTc-DPD) viste allerede etter fem minutter høyt opptak i myokardet og fremdeles høyt opptak etter tre timer (fig 3). Disse funnene var forenlig med transtyretinrelatert hjerteamyloidose. Ut fra familieopplysninger var det ingen holdepunkter for at det skulle være en arvelig form for transtyretinrelatert hjerteamyloidose.

Vi konkluderte med at pasienten hadde en fremskreden senil transtyretinrelatert hjerteamyloidose. Pasientens forverring kunne kanskje ha vært utløst av et hjerteinfarkt, men det var ingen overbevisende dynamikk i troponinverdiene, og ekkokardiografisk undersøkelse viste ingen tegn til infarktsekvele. Vi tolket amyloidoserelatert hjertesvikt samt nyresvikt som sannsynlige årsaker til de forhøyede troponinverdiene, og tidvis rask atrieflimmer kunne forklare variasjonene i verdiene (som holdt seg på omtrent samme forhøyede nivå over tid).

Vi fokuserte videre på konvensjonell hjertesviktbehandling med hovedvekt på diuretika og væskerestriksjon. Pasienten hadde i tiden etter oppholdet flere innleggelser grunnet økende hjertesvikt, i tillegg til flere episoder med synkope. På bakgrunn av syk sinusknute med takykardi-/bradykardi-problemer og økende blokkering i AV-knuten, fikk pasienten senere implantert permanent pacemaker. Pasienten døde seks måneder etter den første innleggelsen.

\section{Diskusjon}

Amyloidose skyldes patogene prosesser der normale eller muterte proteiner endrer form og avleires i forskjellige organer og vev som ekstracellulære, uløselige fibriller (1-3). Disse gir karakteristiske histologiske forandringer, som kan påvises i vevsprøver ved blant annet lysmikroskopi av spesialfargede snitt (1-3). Hos mennesket er det funnet 27 forskjellige proteiner som kan transformeres til amyloid (3). Typen av amyloiddannende protein bestemmer i stor grad hvilke vev og organer som primært affiseres (1-3). De to vanligste årsakene til amyloidavleiring i hjertet er overproduksjon av monoklonale lette immunglobulinkjeder (AL-amyloidose) og transtyretinrelatert sykdom (familiær og senil type), men sjeldne varianter av blant annet fibrinogen og apolipoproteinene A-I og A-II er også beskrevet å kunne gi lidelsen (2). Familiær transtyretinrelatert hjerteamyloidose skyldes mutasjoner i transtyretin og antas å være meget sjelden $\mathrm{i}$ Norge. Senil hjerteamyloidose skyldes utfelling av normale transtyretinproteiner (1). I et uselektert autopsimateriele fra minst 80 år gamle personer viste $25 \%$ av individene amyloidutfelling av normalt transtyretin i hjertet (4), men hos de fleste er denne utfel- 
lingen ikke tilstrekkelig omfattende til å påvirke hjertefunksjonen. Imidlertid bør man spesielt mistenke kardial amyloidose hos eldre menn med biventrikulær hjertesvikt og fortykket myokard uten annen årsak, og det mistenkes at tilstanden er betydelig underdiagnostisert $(2,5)$.

Amyloidavleiring i hjertet disponerer for restriktiv kardiomyopati med utvikling av hjertesvikt. Ekkokardiografi er en tidlig og sentral undersøkelse ved vurdering av både årsaker til og grad av hjertesvikt. Karakteristiske funn ved hjerteamyloidose er biventrikulært fortykkede vegger med god ejeksjonsfraksjon $(5,6)$. Venstre ventrikkels kavitet har normale eller reduserte dimensjoner, og ved reduserte kavitetsdimensjoner (sekundært til vegghypertrofi) er ventrikkelen gjerne hyperkontraktil i tverraksen. Ventrikkelens kontraktilitet i lengdeaksen er derimot redusert allerede tidlig i sykdomsforløpet. Reduksjon av ventrikkelens ejeksjonsfraksjon foreligger først sent i forløpet. Progressiv diastolisk dysfunksjon er et gjennomgående funn (7). Andre vanlige funn ved hjerteamyloidose er forstørrede atrier, mindre til moderat perikardvæskeansamling, myokard med påfallende granulært uttrykk, fortykket atrieseptum og fortykkede papillemuskler og klaffeseil (6). De ekkokardiografiske funnene ved fremskreden hjerteamyloidose gir klar indikasjon på at lidelsen foreligger samt bidrar til å skille den fra aktuelle differensialdiagnoser som Fabrys sykdom, hypertrofisk kardiomyopati og sekundær hypertrofi ved hypertensjon $(6,8)$. En rett diagnose er viktig for vurdering av prognose og valg av behandling.

Forskjellige EKG-forandringer vil gjerne forekomme ved hjerteamyloidose. QRSkompleksene viser ofte tydelig redusert amplitude (low voltage) i ekstremitetsavledningene (6). Kombinasjonen av ventrikulær hypertrofi ved ekkokardiografi og liten QRS-amplitude styrker ytterligere mistanken om denne lidelsen (9). Imidlertid er dette EKG-funnet ikke obligat ved tilstanden, og i en større studie med 127 pasienter med biopsibekreftet hjerteamyloidose ble liten QRS-amplitude bare funnet hos $47 \%$ av pasientene, mens $16 \%$ viste hypertrofikriterier ved vurdering av QRS-kompleksene (10). Spesielt ved de transtyretinrelaterte årsakene kan redusert QRS-amplitude mangle (5). Andre vanlige EKG-funn ved tilstanden er unormal høyre- eller venstredeviasjon av hjerteaksen, pseudoinfarktforandringer, ledningsforstyrrelser og atrieflimmer $(2,6,10)$. Ingen EKG-forandringer er imidlertid patognomoniske for tilstanden. Vår pasients EKG viste ikke lav QRS-amplitude, men viste begynnende overledningsforstyrrelse i AV-knuten og pseudoinfarktforandringer i fremre og laterale vegg (fig 1). Det er grunn til å tro at pasientens syke sinusknute og økende blokkering i AVknuten var relatert til hjerteamyloidosen.

Forskjellige indikatorer er blitt brukt for scintigrafisk påvisning av amyloidose $\mathrm{i}$ for-

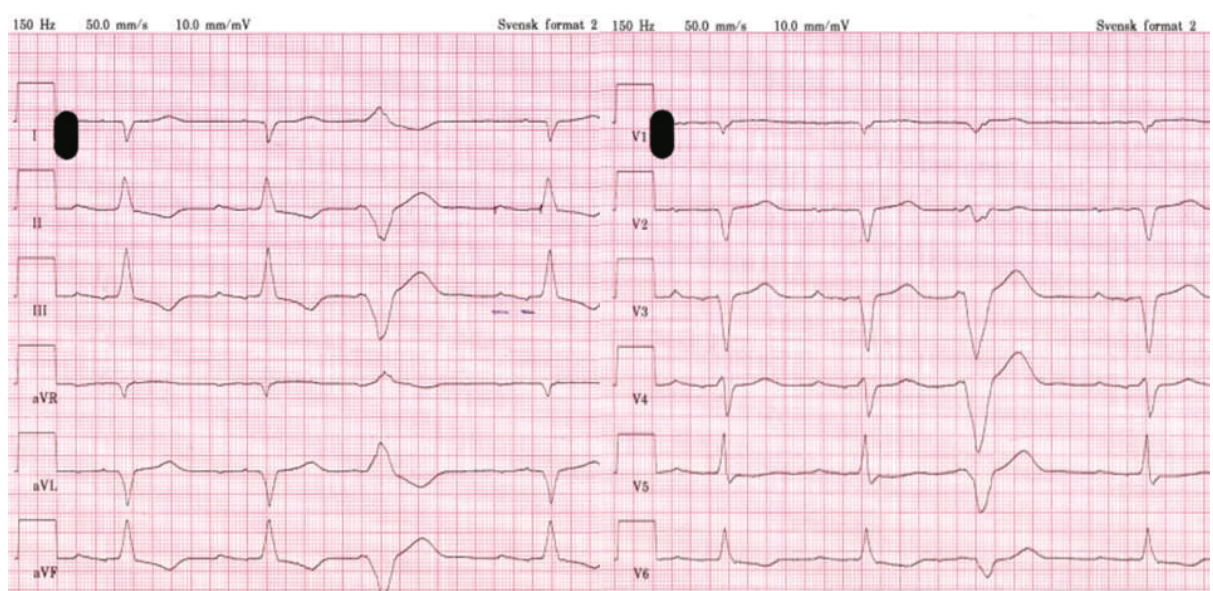

Figur 1 EKG $(50$ mm/s) registrert ved innleggelsen viste sinusrytme, AV-blokk grad 1 med PQ-tid 250 ms, suspekt gjennomgått lateralveggsinfarkt, generelt litt repolariseringsforandringer, dårlig progresjon av R-takkene i mediale prekordialavledninger og spredte ventrikulære ekstrasystoler

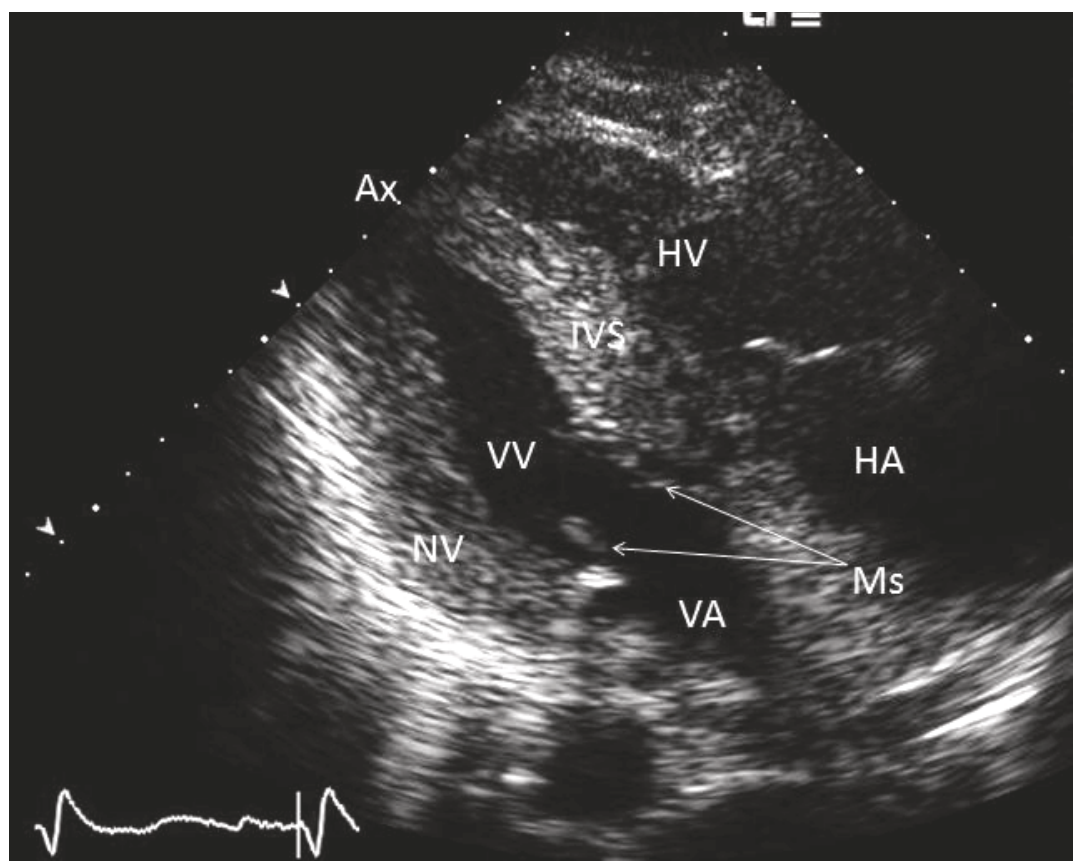

Figur 2 Ekkokardiografi (antydet skrått parasternalt tokammersnitt) viser venstre ventrikkel med hypertrofierte vegger med påfallende granulært uttrykk. Ax = apeks, HA = høyre atrium, HV = høyre ventrikkel, IVS = inter ventrikulærseptum, $M s=$ mitralseil, $N V=$ nedre vegg, $V A=$ venstre atrium, $W=$ venstre ventrikkel

skjellige organer $(2,11)$. En nylig undersøkelse viste at scintigrafi med ${ }^{99 \mathrm{~m} T c-D P D}$ påviste transtyretinrelatert hjerteamyloidose med meget høy sensitivitet og spesifisitet (11) (fig 3). Ved hjerteamyloidose av ulike former vil magnetisk resonans-undersøkelse typisk vise diffust forsterket senopptak av gadolinium i myokardet, mest uttalt subendokardialt $(12,13)$. Hjerteamyloidose kan histologisk bekreftes ved hjertebiopsi, og funn av amyloidnedslag i biopsier fra andre organer som rectum vil indirekte bekrefte diagnosen (2). Biopser fra ekstrakardiale organer har imidlertid lav sensitivitet for påvisning av transtyretinrelatert hjerteamyloidose (14). Nærmere undersøkelser (immunhistokjemiske analyser av amyloidet, DNA-analyser m.m.) kan vise hvilken type amyloidose som foreligger (2).
Hjertet er predileksjonsstedet for avleiring av amyloid ved senil transtyretinrelatert amyloidose. Ved denne typen amyloidose kan avleiring også skje i blant annet lunger, gastrointestinalkanalen og leveren $(2,14)$. Avleiring av amyloid i nyrene angis imidlertid å være uvanlig ved senil hjerteamyloidose, men redusert nyrefunksjon vil ofte foreligge når hjertets pumpefunksjon er blitt tydelig svekket (2). De ekstrakardiale avleiringene av amyloid kan medføre blant annet karpaltunnelsyndrom, ortostatisme og dysmotilitetsplager i tarm $(2,14)$. Slike plager forelå ikke hos vår pasient. Årsaken til nyresvikten ble ikke nærmere utredet, og vi mistenker at nyresvikten først og fremst var sekundær til den svekkede hjertefunksjonen.

Ved hjerteamyloidose har de transtyretin- 

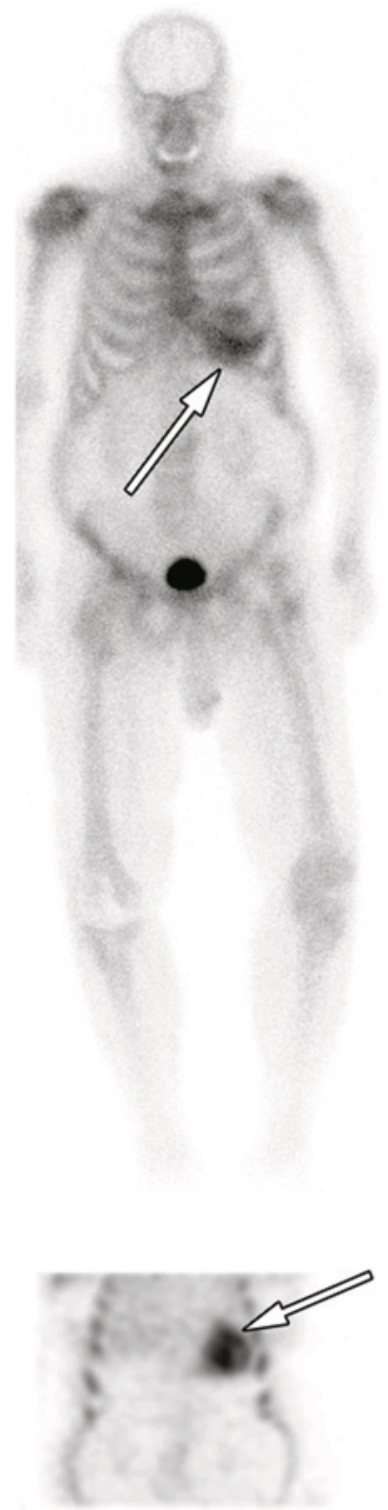

C

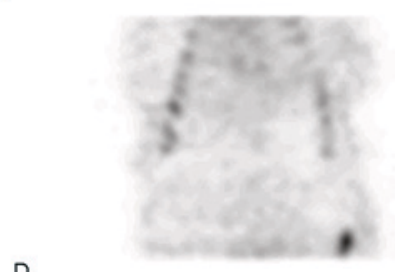

Figur 3 Scintigrafiundersøkelser med ${ }^{99 m}$ Tc-3,3-difosfono-1,2-propandikarboksylsyre (99mTc-DPD). Frontalt bilde (A) og tomografisk (SPECT) frontalsnitt (B) hos vår pasient, med patologisk opptak av 99mTc-DPD i myokard (piler) etter tre timer. Frontalt bilde (C) og representativt tomografisk (SPECT) frontalsnitt (D) hos annen person med normalt hjerte, der undersøkelsen ble gjort på annen indikasjon. C og D viser intet opptak av ${ }^{99 m T C-D P D}$ i myokard. Pasienten fremstilt i figur C og D har gitt samtykke til at bildene gjengis

relaterte formene en bedre prognose enn ALamyloidose $(5,14)$. Ved tilkommet hjertesvikt er imidlertid prognosen dårlig uansett type amyloidose (15). Hjertesvikt behandles etter vanlige retningslinjer, med hovedvekt på diuretika og væskerestriksjon $(6,8)$. Det anbefales forsiktighet med bruk av ACE-hemmere og angiotensin 2-reseptor-blokkere fordi disse pasientene lett utvikler hypotensjon ved bruk av denne type medikamenter, spesielt ved AL-amyloidose $(6,8)$. Digitalispreparater bindes lett til amyloidfibrillene med påfølgende intoksikasjonsfare, og man anbefaler derfor ikke å bruke disse midlene ved tilstanden (16). Levertransplantasjon med eventuell hjertetransplantasjon kan være en mulighet ved den familiære transtyretinrelaterte formen, og hjertetransplantasjon kan vurderes ved AL-amyloidose etter aggressiv behandling av grunnlidelsen (8)

Påvisning av årsaker til hjertesvikt er viktig for valg av behandling og vurdering av prognose. Hos vår pasient var det sannsynligvis ikke arteriell hypertensjon som var utløsende årsak til progressiv hjertesvikt, slik man først hadde antatt. Derimot viste ekkokardiografi distinkte forandringer som ved hjerteamyloidose (fig 2). Den videre utredningen ga ikke holdepunkt for AL-amyloidose, mens scintigrafi med ${ }^{99 m}$ Tc-DPD viste myokardforandringer godt forenlig med transtyretinrelatert hjerteamyloidose (fig 3). Det forelå ikke familiær forekomst av hjertesvikt, og mest sannsynlig hadde pasienten den langt vanligere senile formen av transtyretinrelatert lidelse. Representative biopsier kunne tenkes å ha gitt ytterligere bekreftelse på sykdommen. Ekstrakardiale biopsier har imidlertid lav sensitivitet for transtyretinrelatert amyloidose. Å henvise vår pasient til universitetssykehus for å ta hjertebiopsi syntes unødvendig, ettersom funnene ved ekkokardiografi og scintigrafi gjorde oss sikre på diagnosen. Eventuelle funn ved hjertebiopsi ville neppe endret behandlingen hos denne syke pasienten.

\section{Konklusjon}

Vår pasient fikk påvist en annen årsak til hjertesvikt enn opprinnelig antatt, og kasuistikken setter søkelys på senil hjerteamyloidose, som trolig er underdiagnostisert. Ekkokardiografi og scintigrafi er nyttig for påvisning av tilstanden, og det er viktig å legge merke til at manglende lav QRS-amplitude ikke ekskluderer senil hjerteamyloidose. Lidelsen disponerer for restriktiv kardiomyopati med utvikling av hjertesvikt. Hjertesvikten behandles etter vanlige retningslinjer, med hovedvekt på diuretika og væskerestriksjon og med de forbehold som nevnt over. Digitalispreparater bør ikke brukes ved senil hjerteamyloidose på grunn av intoksikasjonsfare. Ved tilkommet hjertesvikt har senil hjerteamyloidose en alvorlig prognose.

Pasientens pårørende har gitt samtykke til at artikkelen blir publisert.

\section{Anna Widding Langsholdt (f. 1985)}

er for tiden turnuslege ved Sunndal medisinske senter. Hun var inntil august 2012 turnuslege ved Ålesund sjukehus.

Forfatter har fylt ut ICMJE-skjemaet og oppgir ingen interessekonflikter.

\section{Johnny Vegsundvåg (f. 1959)}

er spesialist i kardiologi og indremedisin. Han er overlege ved Kardiologisk seksjon og medlem i Norsk Cardiologisk Selskaps arbeidsgruppe for hjertesvikt.

Forfatter har fylt ut ICMJE-skjemaet og oppgir ingen interessekonflikter.

\section{Litteratur}

1. Falk RH, Comenzo RL, Skinner M. The systemic amyloidoses. N Engl J Med 1997; 337: 898-909.

2. Dubrey SW, Hawkins PN, Falk RH. Amyloid diseases of the heart: assessment, diagnosis, and referral. Heart 2011; 97: 75-84.

3. Wien TN. Behandling av amyloidose. Tidsskr Nor Legeforen 2008; 128: 1397-400.

4. Cornwell GG 3rd, Murdoch WL, Kyle RA et al. Frequency and distribution of senile cardiovascular amyloid. A clinicopathologic correlation. Am J Med 1983; 75: 618-23.

5. Rapezzi C, Merlini G, Quarta CC et al. Systemic cardiac amyloidoses: disease profiles and clinical courses of the 3 main types. Circulation 2009; 120 $1203-12$

6. Falk RH. Diagnosis and management of the cardiac amyloidoses. Circulation 2005; 112: 2047-60. 
7. Klein AL, Hatle LK Burstow DJ et al. Doppler characterization of left ventricular diastolic function in cardiac amyloidosis. J Am Coll Cardiol 1989; 13: 1017-26.

8. Selvanayagam JB, Hawkins PN Paul B et al. Evaluation and management of the cardiac amyloidosis. J Am Coll Cardiol 2007; 50: 2101 - 10

9. Rahman JE, Helou EF, Gelzer-Bell R et al. Noninvasive diagnosis of biopsy-proven cardiac amyoidosis. J Am Coll Cardiol 2004: 43: 410-5.

10. Murtagh B, Hammill SC, Gertz MA et al. Electrocardiographic findings in primary systemic amyloidosis and biopsy-proven cardiac involvement. Am J Cardiol 2005: 95: 535-7.

11. Perugini E, Guidalotti PL, Salvi F et al. Noninvasive etiologic diagnosis of cardiac amyloidosis using 99mTc-3,3-diphosphono-1,2-propanodicarboxylic acid scintigraphy. J Am Coll Cardiol 2005; 46: 1076-84.

12. Vogelsberg $H$, Mahrholdt $H$, Deluigi $C C$ et al. Cardiovascular magnetic resonance in clinically suspected cardiac amyloidosis: noninvasive imaging compared to endomyocardial biopsy. J Am Coll Cardiol 2008; 51: 1022-30.

13. Perugini E, Rapezzi C, Piva T et al. Non-invasive evaluation of the myocardial substrate of cardiac amyloidosis by gadolinium cardiac magnetic resonance. Heart 2006: 92: 343-9.

14. Ng B, Connors LH, Davidoff R et al. Senile systemic amyloidosis presenting with heart failure: comparison with light chain-associated amyloidosis. Arch Intern Med 2005: 165: $1425-9$

15. Klein AL, Hatle LK, Taliercio CP et al. Prognostic significance of Doppler measures of diastolic function in cardiac amyloidosis. A Doppler echocardiography study. Circulation 1991; 83: 808-16.

16. Rubinow A, Skinner M, Cohen AS. Digoxin sensitivity in amyloid cardiomyopathy. Circulation 1981; 63: $1285-8$

Mottatt 1.6. 2012, første revisjon innsendt 4.9. 2012, godkjent 15.10. 2012. Medisinsk redaktør Merete Kile Holtermann.

\section{Kommentar}

\section{Utredning av hjertesvikt - ikke alltid lett}

Pasienter med dyspné er ofte en utfordring for klinikere selv når andre årsaker enn hjertesvikt er ekskludert. Tradisjonelt har diagnosen hjertesvikt (1) vært stilt på bakgrunn av sykehistorie, kliniske funn med ødemer, lungestuvning, halsvenestuvning og eventuelt bilyd over hjertet. Dette suppleres med røntgen thorax og EKG. Blodprøve med analyse av pro-hjernenatriuretisk peptid er de senere årene blitt et verdifullt supplement. Vi kommer således ved hjelp av relativt enkle metoder langt på veien til å få en sikker hjertesviktdiagnose og videre til å kunne skjelne mellom årsaker som klaffesykdom, koronarsykdom eller primær myokardsvikt, f.eks. kardiomyopatier eller myokarditt. Disse tre gruppene omfatter hovedårsakene til hjertesvikt og bør alltid kartlegges og vurderes i diagnostikken. Målrettet behandling med kirurgi, kateterbaserte teknikker, biventrikulær pacing og/eller medikamentell behandling kan dermed innsettes.

Kasuistikken ovenfor viser imidlertid at det ikke alltid er så enkelt og at man kan frarøve pasienter både prognostisk vurdering og kanskje behandlingsmuligheter ved å slå seg til ro med bare diagnosen «hjertesvikt»» eller også «myokardsvikt». Dette gjelder alle aldersgrupper, men spesielt hos eldre.

Denne pasienten hadde fortykkelse av både mitral- og aortaklaff og nedsatt funksjon av venstre hovedkammer. Ekkokardiografi viste funksjonell klaffesykdom. Alvoret av klaffesykdommen er vanskelig å bestemme når det foreligger lavt hjerteminuttvolum, og det krever god erfaring med metoden for å kunne utelukke klaffesykdom som årsak til hjertesvikt i slike tilfeller. Når klaffesykdom ikke alene forklarer hjertesvikten, som i dette tilfellet, er neste spørsmål om man skal slå seg til ro med at det foreligger en uspesifikk myokardsvikt. I dette tilfellet bidro ekkokardiografi til å utelukke tidligere hjerteinfarkt og samtidig gi mistanke om en spesifikk, primær myokardsykdom.

Videre utredning av hjertesvikt kan bestå av biopsitaking, MR med gadoliniumkontrast eller diverse isotopteknikker. $\AA$ ta biopsi fra myokard er en undersøkelse som bare bør utføres på spesialavdelinger ved regionsykehusene. Teknikken har en klar komplikasjonsrisiko som må håndteres akutt, og nytten av svaret som oppnås kan være begrenset dersom ikke indikasjonen vurderes og tyding foretas ved spesialavdeling (2). I noen tilfeller kan biopsi imidlertid være av avgjørende betydning (2), f.eks. ved kjempecellemyokarditt. MR gir i de fleste tilfeller ikke bedre funksjonsvurdering enn ekkokardiografi (1), og kardiologisk MR-diagnostikk er heller ikke tilgjengelig ved de fleste mindre og mellomstore sykehus i landet. Undersøkelsen har sin fremste styrke i bruken av gadoliniumkontrast til å påvise sykdom i myokard, for eksempel for å skjelne mellom iskemisk skade, myokarditt eller kardiomyopatier. Videre utredning med isotopteknikk er mer uvanlig, men funn av restriktiv kardiomyopati ved den ekkokardiografiske undersøkelsen tydet $\mathrm{i}$ dette tilfellet på at undersøkelse med isotopteknikk kunne være nyttig.

Utredning av hjertesvikt krever at man kjenner til relative styrker og svakheter (kontraindikasjoner eller komplikasjoner) ved de forskjellige diagnostiske teknikkene som er tilgjengelige og at man i daglig rutine velger laveste risikonivå på utredningen.

\section{Jan Erik Nordrehaug}

jan.nordrehaug@helse-bergen.no Hjerteavdelingen

Haukeland universitetssykehus

Jan Erik Nordrehaug (f. 1947) er spesialist i hjertesykdommer, klinisk fysiologi og indremedisin og er avdelingssjef.

Forfatter har fylt ut ICMJE-skjemaet og oppgir ingen interessekonflikter.

\section{Litteratur}

1. ESC guidelines for the diagnosis and treatment of acute and chronic heart failure 2012 ESC Com mittee for Practice Guidelines. Eur J Heart Fail 2012; 14: 803-69.

2. Nordrehaug JE. Akutt myokarditt og død - er vi alltid i etterkant? Tidsskr Nor Lægeforen 2006; 126: 2114

Mottatt 24.10. 2012 og godkjent 30.10. 2012 Medisinsk redaktør Merete Kile Holtermann. 